\title{
International Business and Country’s Culture Impact
}

\author{
Gentisa Furxhi
}

\section{ABSTRACT}

International business is very important, nowadays. Businesses, now, compete and operate in an international market. Globalization has created new challenges for managers. Different countries have different cultures, and this make culture a challenge for businesses and managers who operate in international business. They have to pay more attention to the differences of countries cultures they operate with. Sometimes, differences may be seen as insignificant, but they can cause troubles if you don't respect them. Culture's differences may create misunderstandings, conflict, anger even stress in the workplace. People in different culture have different attitudes and behaviors. Organizations have to pay importance to differences in a) communication, b) attitudes c) workplace etiquette d) language.

Albania, after 90', has been an attractive destination for foreign investors. Many investors came in Albania due to her strategic geography position, cheap labor price, informal market, etc.

In this paper we will analyze culture's dimensions according to Hofstede model. Then, we will compare Albanian culture to Italian culture, because Italy is the country which has the majority of foreign companies in Albania.

Keywords: Culture dimensions, globalization, foreign companies, Hofstede model, international business.

Submitted : January 29, 2021

Published : February 9, 2021

ISSN: 2507-1076

DOI: $10.24018 /$ ejbmr.2021.6.1.719

Gentisa Furxhi *

University "Fan S. Noli", Economic

Faculty, Korca, Albania.

(e-mail: gfurxhi@ ${ }^{@}$ gmail.com)

*Corresponding Author

\section{INTRODUCTION}

Today, businesses are operating and competing in a globalized market. Due to globalization, companies, assets, services, capital and people have to move from one country to another. Globalization have created changes to many areas such as economic, social and technological. These changes due to globalization has affected societies and organizations that are part of this process. Different countries have different cultures, and this make culture a challenge for businesses and managers who operate in international business.

There are different definitions about culture, from different authors. Culture is a collective programming of minds that differentiates the members of a human group to another [5]. Other author), defined it (culture) is a collection of values, beliefs, behaviors, habits and attitudes that differentiate societies [4].

Sometimes, organizations prefer to open their activities in countries that have culture similar to their own country.

Organization and managers that operate in international business have to be informed about the culture of countries they are working with. If they are misinformed, this may cause conflict in their relationships [2].

People in different culture have different attitudes and behaviors. Organizations have to pay importance to differences in a) communication, b) attitudes c) workplace etiquette d) language.

\section{CULTURE DimENSIONS}

Geert Hofstede (a Dutch psychologist) conducted one of the earliest and best-known cultural studies in management [1]. He developed the Hofstede model which has six dimensions for national culture. This model is useful to understand national differences, explained in six dimensions as it is shown in Fig. 1.

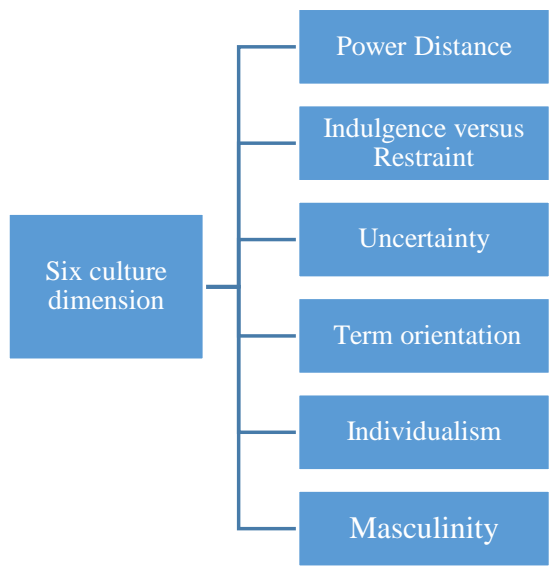

Fig. 1. Six culture dimensions adapted by hofstede model. 


\section{A. Power Distance}

As we know, individuals are not equal in their societies. Power distance dimension explains how power is distributed among individuals in a society and how individuals with less power accept this power distributional. Societies, which have low power distance, are more democratic than

\section{B. Individualism Versus Collectivism}

This dimension is about the relative importance of individual versus group interests. In Individualist societies people are supposed to look after themselves and their direct family only. In Collectivist societies people belong to 'in groups' that take care of them in exchange for loyalty.

\section{Masculinity Versus Femininity}

The Masculinity/Femininity dimension is about what values are considered more important in a society. A masculine prefers different values than a feminist society. Masculine society is more given in achievement, heroism, assertiveness and material rewards for success. On the other hand, feminist society prefers cooperation, modesty, caring for the weak and quality of life. Masculine society is more competitive, and it is categorized as a tough society, while feminist society is more consensus-oriented and it is considered as a tender one.

\section{Uncertainty}

The Uncertainty Avoidance dimension expresses the degree to which the members of a society feel uncomfortable with uncertainty and ambiguity. The fundamental issue here is how a society deals with the fact that the future can never be known: should we try to control the future or just let it happen? Countries exhibiting a high Uncertainty Avoidance maintain rigid codes of belief and behavior and are intolerant of unorthodox behavior and ideas. These countries often need many rules to constrain uncertainty. Countries with a low Uncertainty Avoidance index maintain a more relaxed attitude in which practice counts more than principles, tolerance for ambiguity is accepted and the need for rules to constrain uncertainty is minimal. South American countries such as Chile, Peru and Argentina are highly uncertainty avoiding countries.

\section{E. Long - Versus Short - Term Orientation}

This dimension explains how individual conceive time. Short term orientation societies are more traditional and pass a lot of time to create good relationships. These societies see time as a vicious circle, where future and present are connected. Long term orientation societies are future oriented. Individuals in these societies evaluate the results.

\section{F. Indulgence Versus Restraint}

This dimension measure how people control their desires and impulses. Indulgence is referred to weak control and strong control is called Restraint. Restraint society has strict social norms.

\section{Albanian CUlture COMPARED With ITALIAN CUL- TURE}

After 90's, Albania has been an attractive destination for foreign investors. Many investors came in Albania due to her strategic geography position, cheap labor price, informal market, etc. There are many foreign companies that operate in Albania, the number, of foreign companies till 2018 [6], is shown at the figure below (Fig. 2).

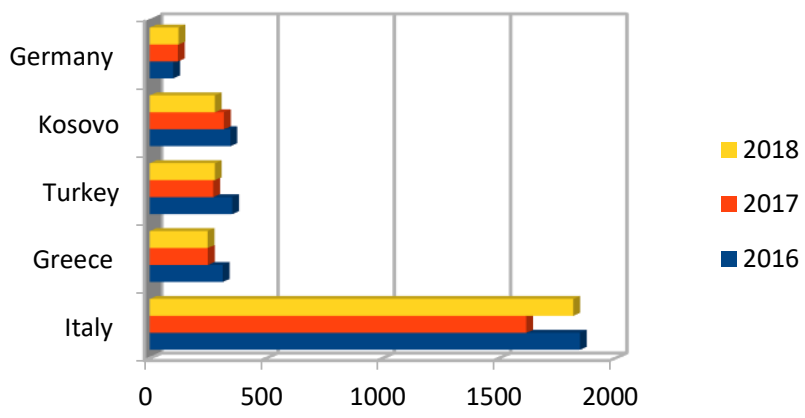

Fig. 2. Foreign companies operating in Albania 2016-2018. Source: Adapted by [6].

The majority of foreign companies are Italian. That is why we will compare Albanian and Italian culture, to see how different they are. Cultures of these two countries are as it is shown to the figures below [7], (Fig. 3, 4).

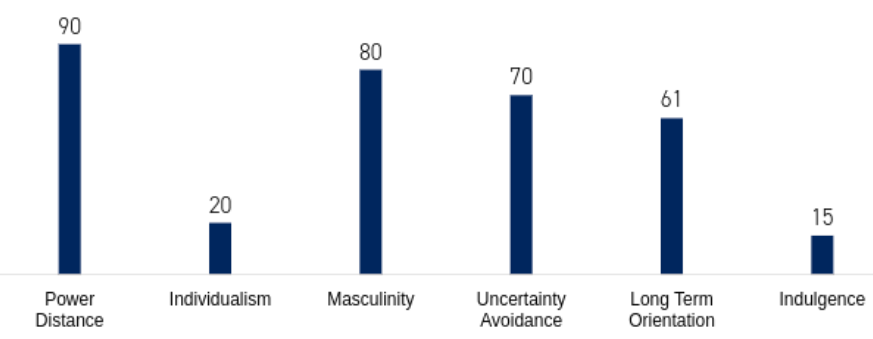

Fig. 3. Albania culture according to six dimensions of hofsdede's model. Source: [7].

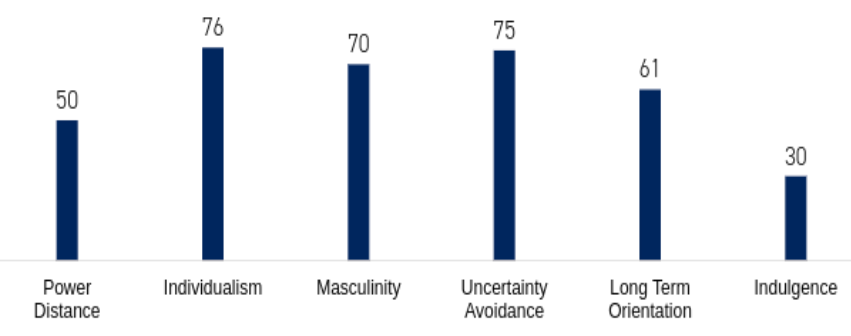

Fig. 4. Italian culture according to six dimensions of hofstede's model. Source: [7].

As we can see from the Fig. 3, Albania has a high score in power distance. That is why Albania is a hierarchical society. Individuals in this society respect orders came from the others who are in higher positions. Also, Albania can be considered a 
"Masculine" society. Individuals are more concerned in achievements and material rewards. Albanian people are proud of their successes and achievements in life, and these offer a basis for hiring and promotion decisions in the workplace.

On the other hand, Italy has an individualist culture (70 score). In the North part of Italy, which is the most developed part of the country, people can feel alone even if they are surrounded by other people. For Italians is very motivating having their personal ideas and objectives in their lives. Italian people believe in happiness and they appreciate that personal fulfillment brings happiness in life. Italian also has a high score of uncertainty avoidance. Which mean that formality is important in this society. We can say that both Italy and Albania are masculine society.

\section{CONCLUSIONS}

This study has analyzed the importance of country's culture in International Business. Also, we explained Hofstede's model of culture dimension and we compared Albanian culture and Italian culture according to these dimensions. Some of this study conclusions are:

- Many organizations want to be part of international business going far beyond their country borders.

- Due to globalization, companies, assets, services, capital and people have to move from one country to another.

- Different countries have different cultures, and this make culture a challenge for businesses and managers who operate in international business.

- Organization and managers that operate in international business have to be informed about the culture of countries they are working with. If they are misinformed, this may cause conflict in their relationships.

- Albania is a hierarchical and masculine society. Individuals are more concerned in achievements and material rewards.

- Italy has an individualist culture, also has a high score of uncertainty avoidance. Italian people believe in happiness and they appreciate that personal fulfillment brings happiness in life.

\section{REFERENCES}

[1] G. Hofstede et al., "What Goals Do Business Leaders Pursue? A Study in Fifteen Countries," Journal of International Business Studies, vol. 33, no. 4, 2002 pp. 785-804. 11.

[2] G. Hofstede, Culture's Consequences: "Comparing Values, Behaviors, Institutions and Organizations across Nations", 2nd ed. Thousand Oaks, CA: Sage, 2001.

[3] Glinka, B., \& Thatchenkery, T. "A comparative study of perceptions towards entrepreneurship in India, Poland, and the USA". International Journal of Human Resource, 2013.

[4] Griffin R. W.; Pustay M.W. International Business: a managerial perspective. $2^{\text {nd }}$. Addison Wesley: New York, 1999.

[5] Hofstede, G. Culture's consequence: "International difference in the work related values". Sage Publication: Beverly Hills, CA, 1984.

[6] Instat: Bizneset e Huaja në Shqipëri 2016-2018; dhjetor, 2019.

[7] https://www.hofstedeinsights.com/product/compare-countries/.

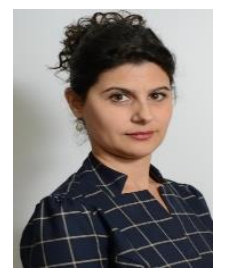

Gentisa Furxhi is a Phd. Candidate in the Economic Faculty of Tirana University. She is an assistant Lecture of the Economic Faculty of "Fan S. Noli" University of Korca. She has a bachelor degree in Business Management at the Economic Faculty of Korca University; The Master degree of Management Hospitality at the "Sv. Kliment Ohridski", North Macedonia. 